\title{
HUBUNGAN STATUS GIZI TERHADAP USIA MENARCHE SISWI MADRASAH IBTIDAIYAH MUHAMMADIYAH KISMOYOSO NGEMPLAK BOYOLALI
}

\author{
Retno Dewi Noviyanti ${ }^{1}$, Sri Mintarsih ${ }^{2}$, Sansavera Nur Fatimah ${ }^{3}$
}

\begin{abstract}
Background : Menarche is the first period that is common in the age range 10-16 years or in early adolescence middle of puberty before entering the reproductive period. Research of Aishah (2011) concluded that female students who have higher nutritional status (BMI) will get menarche faster. Likes research of Munda et al (2012) concluded that female students with overweight get menarche faster than female students with normal and underweight category.

Methods : This research used a deskriptif kuantitatif, retrospective study approach. This research was conducted in Madrasah Ibtidaiyah Muhammadiyah Kismoyoso Ngemplak Boyolali. Research subjects were used female students of elementary school in grade $\mathrm{V}$ and $\mathrm{VI}$, with total sampling metode consist of 15 students who had experienced menarche. The data of the research were analyzed by using Pearson Product Moment formula. This formula used to analysis the relationship between nutritional status with the age of menarche of female students of Madrasah Ibtidaiyah Muhammadiyah Kismoyoso Ngemplak Boyolali.

Result and Conclusion : The average of nutritional status based on percentage of Weight for Age was $-87,9 \pm 14,2$, normal category $73.3 \%$, middle category $20 \%$ and underweight $6.7 \%$. The average of the age of menarche of female students was $141.7 \pm 10.7$ month, with normal category age of menarche $100 \%$. The results of Pearson Product Moment test was $p=0.104$.

Based on the results of the research can be concluded that there was no relationship between the nutritional status with the age of menarche of female students of Madrasah Ibtidaiyah Muhammadiyah Kismoyoso Ngemplak Boyolali.
\end{abstract}

Keywords: female students of elementary school, menarche, nutritional status.

\section{LATAR BELAKANG}

Menarche merupakan tanda berfungsinya organ reproduksi dan sistem endokrin yang akan bermanifestasi pada polikistik ovarium syndrome dan resiko kanker payudara. Beberapa penelitian membuktikan bahwa berat badan sewaktu lahir dan berat badan yang overweight dapat menentukan usia terjadinya menarche.

Menarche merupakan menstruasi pertama yang biasa terjadi pada rentang usia 10-16 tahun atau pada masa awal remaja ditengah pubertas sebelum memasuki masa reproduksi. Menarche merupakan suatu tanda awal adanya perubahan lain seperti pertumbuhan payudara, pertumbuhan rambut di pubis dan aksila, serta distribusi lemak pada daerah pinggul. Faktor-faktor yang mempengaruhi usia menarche di antaranya adalah status gizi, sosial ekonomi, kelainan fisik, audio visual, lingkungan sosial dan genetik (Proverawati dan Misaroh, 2009).

Membaiknya standar kehidupan berdampak pada penurunan usia menarche ke usia yang lebih muda. Penelitian yang dilakukan 
McAnarney (2003) menyatakan umur menarche remaja putri di Amerika mengalami penurunan dari 12,75 tahun menjadi 12,54 tahun. Di Indonesia usia remaja pada waktu menarche bervariasi antara 10 hingga 16 tahun dan rata-rata menarche pada usia 12,5 tahun (Prawirohardjo, 2009). Penelitian Aishah (2011) menyebutkan bahwa rata-rata usia menarche pada siswa SD dan SMP Shafiyyatul Amaliyyah adalah 11,62 tahun $\pm 0,73$ SD.

Menarche dini dipengaruhi oleh beberapa faktor salah satunya adalah status gizi. Status gizi adalah keadaan tubuh sebagai akibat konsumsi makanan dan penggunaan zat-zat gizi (Muliadi, 2007). Status gizi dapat pula diartikan sebagai tanda fisik yang diakibatkan oleh karena adanya keseimbangan antara pemasukan dan pengeluaran gizi melalui variabel-variabel tertentu (Linder, 2006). Sedangkan status gizi optimal adalah suatu keadaan dimana terdapat keseimbangan antara asupan dengan kebutuhan zat gizi yang digunakan untuk aktifitas sehari-hari (Soekirman, 2000).

Pada anak-anak dengan kelebihan berat badan akan terjadi peningkatan sekresi leptin. Makin tinggi kadar leptin, makin cepat terjadi menarche. Nutrisi mempengaruhi kematangan seksual pada gadis yang mendapat mentruasi pertama lebih dini, mereka cenderung lebih berat dan lebih tinggi pada saat mentruasi pertama dibandingkan dengan mereka yang belum mentruasi pada usia yang sama. Tikus percobaan yang mendapat rendah gizi, didapatkan mengalami keterlambatan menstruasi dan memiliki pituitary gonadotropin releasing hormone ( $\mathrm{GnRH})$ kadarnya rendah dan reseptor $\mathrm{GnRH}$ dalam jumlah sedikit. Keadaan akan berbalik apabila asupan nutrisinya diperbaiki dan fungsi hormon menjadi normal kembali serta kematangan seksual dapat berlangsung (Soetjiningsih, 2004).

Protein berfungsi dalam sintesis beberapa hormon yang penting bagi remaja putri, yaitu hormon estrogen, progesteron, hormon lutinasi (luteinizing hormone/LH) dan hormon perangsang folikel (folikel stimulating hormone/FSH) yang berperan ketika mereka memasuki masa pubertas, yaitu masa menstruasi awal yang dikenal dengan istilah menarche. Kelebihan konsumsi karbohidrat dan lemak juga dapat memicu terjadinya menstruasi (menarche) dini akibat kelebihan berat badan (obesitas). Penelitian yang dilakukan Dr. Rajalaksmi Laksmana dari Universitas Cambridge menyatakan sebagian besar kasus menstruasi dini berkaitan dengan jumlah lemak di dalam tubuh perempuan. Saat ini, anak remaja yang status gizinya baik mengalami awal pubertas yang sesuai dengan usia dibandingkan dengan remaja yang bertubuh kurus atau yang memiliki gizi dibawah normal (Soetjatiningsih, 2004). Perbaikan gizi atau asupan gizi yang baik dapat menyebabkan umur haid pertama menjadi lebih dini (Abudayya dkk (2009) dalam buku Waryono, 2010).

Penelitian Archarya et al (2006) menyimpulkan bahwa semakin rendah IMT (Indeks Masa Tubuh) pada remaja putri, maka umur menarche akan semakin lambat. Pernyataan ini sejalan dengan penelitian Aishah (2011) menyimpulkan bahwa siswi yang memiliki status gizi (IMT) yang lebih tinggi cenderung mendapatkan menarche lebih cepat. Seperti hasil penelitian Munda, dkk (2012) bahwa siswi dengan status gizi overweight lebih cepat mengalami menarche 
dibandingkan siswi yang berstatus gizi normal dan underweight.

Berdasarkan penelitian Aribowo (2004) ada hubungan yang negatif antara status gizi berdasarkan indeks TB/U dengan usia menarche, yang berarti semakin tinggi status gizi semakin cepat usia menarchenya. Namun tidak ada hubungan antara status gizi berdasarkan indeks BB/TB dengan usia menarche. Hasil penelitian Munda, dkk (2012) menyatakan terdapat hubungan yang sangat bermakna antara status gizi berdasarkan IMT dan usia menarche.

Hasil survei pendahuluan di MIM Kismoyoso Ngemplak Boyolali didapatkan terdapat 35\% siswi yang sudah mengalami menarche.saat ini masih jarang penelitian tentang status gizi berdasarkan indeks BB/U terhadap usia menarche.

Berdasarkan uraian tersebut peneliti ingin meneliti tentang "Hubungan status gizi berdasarkan indeks \% BB/U terhadap usia menarche di Madrasah Ibtidaiyah Muhammadiyah Kismoyoso Ngemplak Boyolali”.

\section{TUJUAN PENELITIAN}

1. Tujuan Umum

Mengetahui hubungan status gizi berdasarkan indeks \% BB/U terhadap usia menarche di Madrasah Ibtidaiyah Muhammadiyah Kismoyoso Ngemplak Boyolali.

2. Tujuan Khusus

a. Mendiskripsikan status gizi
siswi MIM Kismoyoso
Ngemplak Boyolali.
b. Mendeskripsikan usia
menarche siswi MIM Kismoyoso Ngemplak Boyolali.

c. Menganalisa hubungan status gizi berdasarkan indeks \% BB/U terhadap usia menarche siswi Madrasah Ibtidaiyah
Muhammadiyah Kismoyoso

Ngemplak Boyolali.

\section{METODE PENELITIAN}

Penelitian ini menggunakan studi penelitian deskriptif kuantitatif dengan metode studi korelasi untuk memperoleh informasi hubungan antara dua variabel pada suatu situasi atau sekelompok subjek (Notoatmodjo, 2012) dengan pendekatan retrospektif. Penelitian dilakukan di Madrasah Ibtidaiyah Muhammadiyah Kismoyoso Ngemplak Boyolali, pada tanggal 23 Mei 2015 terhadap siswi kelas $V$ dan $\mathrm{VI}$ dengan penentuan sampel dengan menggunakan metode total sampling dengan jumlah 15 siswi yang sudah mengalami menstruasi.

Variabel penelitian ini terdiri dari variabel bebas yaitu status gizi dan variabel terikat yaitu usia menarche.

Analisis data dilakukan dengan menggunakan program SPSS for Windows versi 17.0. Data dianalisis secara statistik dengan proses sebagai berikut: analisis univariat bertujuan untuk mendeskripsikan karakteristik responden dan variabel penelitian. Data-data variabel penelitian dalam bentuk kategori dideskripsikan dalam prosentase dan data-data variabel penelitian dalam bentuk numerik dideskripsikan dalam $\mathrm{n}$, mean dan standar deviasi.

Analisis statistik untuk mengetahui hubungan status gizi berdasarkan indeks BB/U terhadap usia menarche di Madrasah Ibtidaiyah Muhammadiyah Kismoyoso Ngemplak Boyolali dengan uji hubungan/korelasi yang didahului dengan uji kenormalan data menggunakan uji KolmogorovSmirnov, dengan tujuan untuk mengetahui jenis analisis statistik yang akan digunakan, data dikatakan normal jika nilai $p \geq 0,05$. 
Hasil uji normalitas data diperoleh distribusi data normal, sehingga uji hubungan menggunakan Pearson Product Moment. Bila $p$ value $<0,05$ maka ada hubungan status gizi berdasarkan indeks \% BB/U terhadap usia menarche di Madrasah Ibtidaiyah Muhammadiyah Kismoyoso Ngemplak Boyolali dan apabila $p$ value $\geq 0,05$ maka tidak ada hubungan status gizi berdasarkan indeks \% BB/U terhadap usia menarche di Madrasah Ibtidaiyah Muhammadiyah Kismoyoso Ngemplak Boyolali.

\section{HASIL PENELITIAN}

1. Karakteristik Penelitian

Responden menarche

Tabel 1

Usia Menarche Siswi

\begin{tabular}{ccc}
\hline Umur $($ bln $)$ & $f$ & $\%$ \\
\hline $120-129$ & 1 & 6,7 \\
$130-139$ & 8 & 53,3 \\
$140-149$ & 3 & 20 \\
$150-159$ & 2 & 13,3 \\
$>160$ & 1 & 6,7 \\
Total & 15 & 100 \\
\hline
\end{tabular}

Berdasarkan tabel 1, dapat disimpulkan bahwa usia responden saat mengalami menarche sebagian besar adalah pada rentang umur 130-139 bulan yaitu 53,3 \%, yang paling sedikit pada rentang umur 120-129 bulan dan $>160$ yaitu $6,7 \%$.
2. Variabel penelitian

a. Data numerik

Tabel 2

Data Penelitian Bentuk Numerik

\begin{tabular}{ccc}
\hline & $\begin{array}{c}\text { Status gizi } \\
\text { BB/U (\%) }\end{array}$ & $\begin{array}{c}\text { Usia } \\
\text { menarche } \\
\text { (bulan) }\end{array}$ \\
\hline & 15 & 15 \\
\hline Mean & 87,9 & 141,7 \\
\hline Median & 88 & 139 \\
\hline Stdr.Deviasi & 14,2 & 10,7 \\
\hline Minimum & 63 & 127 \\
\hline Maksimum & 116 & 162 \\
\hline
\end{tabular}

Berdasarkan tabel 2, dapat disimpulkan bahwa rata-rata status gizi berdasarkan \% $\mathrm{BB} / \mathrm{U}$ responden dalam penelitian ini adalah baik dengan nilai \% BB/U 87,9 \pm 14,2. Sedangkan usia menarche rata-rata terjadi pada usia normal dengan usia $141,7 \pm 10,7$ bulan.

b. Data kategori

1) Status gizi

Status gizi ditentukan menggunakan indeks \% BB/U. Kategori status gizi dapat dilihat pada tabel 3 berikut ini:

Tabel 3

Kategori Status Gizi

\begin{tabular}{ccc}
\hline $\begin{array}{c}\text { Kategori Status } \\
\text { gizi }\end{array}$ & $\mathrm{f}$ & $\%$ \\
\hline Kurang & 1 & 6,7 \\
Sedang & 3 & 20 \\
Baik & 11 & 73,3 \\
Total & 15 & 100 \\
\hline
\end{tabular}

Berdasarkan tabel 3 dapat disimpulkan bahwa dari 15 siswi, sebanyak 73,3 \% siswi memiliki status gizi normal dan sebanyak 26,7 $\%$ status gizi tidak normal yang terdiri dari , 6,7 \% kurang dan $20 \%$ sedang. 
2) Usia menarche rata-rata Kategori usia menarche rata-rata siswi dapat dilihat pada tabel 4 berikut ini:

Tabel 4

Kategori Usia Menarche Rata-Rata Siswi

\begin{tabular}{ccc}
\hline Kategori Usia & $f$ & $\%$ \\
\hline Normal & 15 & 100 \\
Total & 15 & 100
\end{tabular}

Berdasarkan tabel 4 dapat disimpulkan bahwa dari semua responden dalam penelitian ini $100 \%$ mengalami usia menarche pada rentang usia normal.

3. Analisis hubungan antar variabel penelitian

Tabel 5

Hasil Uji Hubungan Status Gizi Terhadap Usia Menarche

\begin{tabular}{lcc}
\hline Variabel & $\begin{array}{c}\mathrm{P} \\
(\mathrm{uji} \\
\text { kenormalan) }\end{array}$ & $\mathrm{P}$ value \\
\hline $\begin{array}{c}\text { Status gizi } \\
\text { Usia } \\
\text { menarche }\end{array}$ & $\begin{array}{c}1,000^{\mathrm{a}} \\
{ }^{\mathrm{a}} \text { Kolmogorov-Smirnov } \\
{ }^{\mathrm{b}} \text { Pearson Product Moment }\end{array}$ & $0,104^{\mathrm{b}}$ \\
&
\end{tabular}

Berdasarkan hasil analisis statistik hubungan status gizi berdasarkan indeks \% BB/U terhadap usia menarche yang didahului dengan uji kenormalan dengan uji statistik KolmogorovSmirnov diketahui bahwa data status gizi $(p=1,000)$ dan usia menarche $(p=0,579)$ berdistribusi normal sehingga untuk uji hubungan menggunakan uji statistik Pearson Product Moment diketahui bahwa tidak terdapat hubungan status gizi terhadap usia menarche dengan nilai $p=0,104$.

\section{PEMBAHASAN}

Menarche merupakan menstruasi pertama yang biasa terjadi pada rentang usia 10-16 tahun atau pada masa awal remaja ditengah pubertas sebelum memasuki masa reproduksi. Menarche merupakan suatu tanda awal adanya perubahan lain seperti pertumbuhan payudara, pertumbuhan rambut di pubis dan aksila, serta distribusi lemak pada daerah pinggul. Faktor-faktor yang mempengaruhi usia menarche di antaranya adalah status gizi, sosial ekonomi, kelainan fisik, audio visual, lingkungan sosial dan genetik (Proverawati dan Misaroh, 2009).

Titik kritis ukuran antopometri pencetus menstruasi dini adalah berat badan $40 \mathrm{~kg}$ dan tinggi badan $148 \mathrm{~cm}$. Terdapat hubungan antara massa lemak tubuh dengan kejadian menarche dini, begitu pula dengan hubungan status gizi berdasarkan $\mathrm{BMI}$ dengan usia menarche (Waryono, 2010).

Dari data penelitian ini terdapat 6,7 $\%$ siswi mengalami gizi kurang, 20\% status gizi sedang dan $73,3 \%$ status gizi baik. Untuk usia menarche $100 \%$ terjadi menarche pada usia normal. Dengan rata-rata status gizi berdasarkan \% BB/U dalam kategori baik dengan nilai \% BB/U 87,9 \pm 14,2. dan usia menarche rata-rata terjadi pada usia normal dengan usia $141,7 \pm 10,7$ bulan atau 11 tahun 8 bulan. Hasil ini tidak jauh beda dengan hasil penelitian Aishah (2011) menyebutkan bahwa ratarata usia menarche pada siswa SD dan SMP Shafiyyatul Amaliyyah adalah 11,62 tahun $\pm 0,73$ SD.

Berdasarkan hasil riset kesehatan dasar tahun 2010, 5,2 \% anak di 17 provinsi di Indonesia telah memasuki usia menarche dibawah usia 12 tahun. Indonesia sendiri menempati urutan ke-15 dari 67 negara dengan penurunan usia menarche mencapai 
0, 145 tahun per-dekade (Santrock, 2003). Di Indonesia usia remaja pada waktu menarche bervariasi antara 10 hingga 16 tahun dan ratarata menarche pada usia 12,5 tahun.

Hasil ini menunjukkan bahwa saat ini telah terjadi pergeseran usia menarche ke usia yang lebih muda dibandingkan dengan generasi sebelumnya. Hal ini juga diperkuat oleh penelitian yang dilakukan oleh McAnarney (2003) di Amerika Serikat yang menunjukkan usia menarche rata-rata telah berkurang dari 12,75 kepada 12,54 tahun. Pada penelitian yang sama di Netherlands, menunjukkan usia pubertas rata-rata telah berkurang dari 11 tahun ke 10,7 tahun.

Penelitian ini ingin mengetahui hubungan status gizi berdasarkan indeks \% BB/U terhadap usia menarche. Uji statistik yang digunakan adalah Pearson Product Moment diketahui bahwa tidak ada hubungan status gizi terhadap usia menarche di MIM Kismoyoso, dengan nilai $p=0,104$. Hal ini dapat dibuktikan terdapat siswi dengan status gizi kurang mengalami menarche lebih awal dari teman sebayanya. Penelitian ini sejalan dengan penelitian Aribowo (2004) yang menyatakan bahwa tidak ada hubungan antara status gizi berdasarkan indeks BB/TB dengan usia menarche.

Namun berdasarkan penelitian Munda, dkk (2012) menyatakan terdapat hubungan yang sangat bermakna antara status gizi berdasarkan IMT dan usia menarche pada siswi SD dan SMP di Kota Manado, siswi dengan status gizi overweight lebih cepat mengalami menstruasi dibandingkan siswi yang berstatus gizi normal dan underweight. Ternyata yang lebih mempengaruhi usia menarche adalah IMT yaitu indeks massa tubuh yang berisi berat badan dibagi tinggi badan dalam kuadrat bukan berat badan dan umur saja.

Pernyataan tersebut didukung oleh penelitian Aishah (2011) terdapat perbedaan rata-rata usia menarche antara kelompok status gizi malnutrisi, normal, overweight dan obesitas pada siswa SD dan SMP Shafiyyatul Amaliyyah. Terdapat hubungan antara status gizi dengan usia menarche pada siswa SD dan SMP Shafiyyatul Amaliyyah. Hal ini sejalan dengan penelitian Wirasenta (2011), yang dilakukan pada siswi SD di Provinsi Nusa Tenggara Barat, yang menyatakan bahwa terdapat hubungan antara status gizi dan usia menarche.

Pada penelitian ini didapat hasil tidak ada hubungan status gizi terhadap usia menarche di MIM Kismoyoso Ngemplak Boyolali hal ini dapat terjadi karena jumlah sampel yang terlalu sedikit atau ada faktor lain yang mempengaruhi usia menarche yang tidak diteliti.

Dalam penelitian Susanti dan Sunarto (2012) yang meneliti tentang faktor resiko kejadian menarche dini pada remaja di SMPN 30 Semarang, mengatakan bahwa rendahnya asupan serat dan tingginya asupan lemak maupun kalsium, dimana faktor resiko yang paling dominan adalah asupan serat yang rendah. Riwayat ibu yang mengalami menarche dini dan asupan tinggi protein hewani beresiko kecil terhadap kejadian menarche dini.

Selain itu menurut Proverawati dan Misaroh (2009), faktor yang mempengaruhi menarche adalah faktor lingkungan Menurut sebuah penelitian menyatakan bahwa lingkungan sosial berpengaruh terhadap waktu tejadinya menarche. Lingkungan keluarga yang harmonis dan adanya keluarga yang harmonis 
dapat memperlambat terjadinya menarche dini sedangkan anak yang tinggal ditengah-tengah keluarga yang tidak harmonis dapat mengakibatkan terjadinya menarche dini.

Pada hasil penelitian ini dapat disimpulkan bahwa usia menarche dapat terjadi pada siswi dengan segala status gizi (obesitas, baik, sedang, kurang). Status gizi bukanlah satu-satunya faktor yang mempengaruhi usia menarche.

\section{KESIMPULAN DAN SARAN}

1. Kesimpulan

a. Status gizi siswi Madrasah Ibtidaiyah Muhammadiyah Kismoyoso Ngemplak Boyolali berdasarkan \% median BB/U memiliki rata-rata status gizi saat menarche adalah $87,9 \pm$ $14,2 \%$ dengan rincian $73,3 \%$ siswi memiliki status gizi baik, $20 \%$ sedang dan 6,7 \% kurang.

b. Usia menarche siswi Madrasah Ibtidaiyah Muhammadiyah Kismoyoso Ngemplak Boyolali rata-rata pada usia 141,7 $\pm 10,7$ bulan atau 11 tahun 8 bulan.

c. Tidak ada hubungan status gizi berdasarkan indeks \% BB/U terhadap usia menarche pada siswi Madrasah Ibtidaiyah Muhammadiyah Kismoyoso Ngemplak Boyolali dengan $p$ value $=0,104$ pada signifikan $5 \%$.

2. Saran

Bagi peneliti selanjutnya diharapkan dapat melakukan penelitian dengan variabel bebas yang lebih lengkap terkait hal-hal yang mempengaruhi usia menarche.
DAFTAR PUSTAKA

Aishah, S. 2011. Hubungan antara Status Gizi dengan Usia Menarche pada siswa Sekolah Dasar (SD) dan Sekolah Menengah Pertama (SMP) Shafiyyatul Amaliyyah Medan Tahun 2011. Skripsi. Universitas Sumatera Utara, Medan.

Archarya et al. 2006. "Nutritional Status and Menarche in Adolescent Girls in an Urban Resettlement Colony of South Delhi". Indian Journal of Community. OctoberDecember Vol. 31, No.4.

Aribowo, AA. 2004. Hubungan Status Gizi (Indeks BB/TB dan $T B / U)$ dengan Usia Menarche pada Siswi Smp Negeri Di Kecamatan Pati Kabupaten Pati. Skripsi. Universitas Diponegoro, Semarang.

Linder. 2006. Nutritional biochemistry and Metabolism: Nutrition and Metabolism of The Trace Element. Elseint, New York.

McAnarney, Elizabeth R. 2003. "Decreasing Age at Menarche : Is The End in Sight?" Journal Watch Pediatrics and Adolescent Medicine.

Muliadi. 2007. "Peranan Gizi yang Berkualitas dalam Mencegah Malnutrisi pada Anak Sekolah Dasar". Jurnal Samudra IImu.

Munda, SS, Wagey, FW, Wantania, J. 2012. Hubungan Antara Imt Dengan Usia Menarche pada Siswi SD dan SMP di Kota Manado. Fakultas Kedokteran Universitas Sam Ratulangi, Menado. 
Notoatmodjo, Soekidjo. 2012. Metodologi Penelitian Kesehatan. Rineka Cipta, Jakarta.

Prawirohardjo, Sarwano. 2009. IImu Kandungan. Edisi 2. PT Bina Pustaka, Jakarta.

Proverawati, A dan Misaroh, S. 2009. Menarche: Menstruasi Pertama Penuh Makna. Nuha Medika, Yogyakarta.

Santrock JW. 2003. Adolescence: Perkembangan Remaja. Edisi 6. Erlangga, Jakarta.

Soekirman. 2000. IImu Gizi Dan Aplikasinya: untuk Keluarga dan Masyarakat. Direktorat Jendral Pendidikan Tinggi Departemen Pendidikan Nasional, Jakarta.

Soetjiningsih. 2004. Tumbuh Kembang Remaja dan Permasalahannya. CV Agung Seto, Jakarta.
Susanti, AV dan Sunarto. 2012. Faktor Resiko Kejadian Menarche Dini Pada Remaja Di SMPN 30 Semarang. Skripsi. Universitas Diponegoro, Semarang.

Waryono. 2010. Gizi Reproduksi. Pustaka Rihana, Yogyakarta.

Wirasenta L. 2011. "Hubungan Status Gizi Anak, Status Sosial ekonomi Orang Tua dan Paparan Media Dengan Usia Menars pada Siswi Sekolah Dasar (SD) Provinsi Nusa Tenggara Barat". URL: http://www.pps.unud.ac.id.

Diakses pada tanggal Juli 2015.

1. Dosen STIKES PKU

Muhammadiyah Surakarta

2. Dosen STIKES PKU Muhammadiyah Surakarta

3. Mahasiswa STIKES PKU Muhammadiyah Surakarta 